\title{
PENGARUH MODEL PEMBELAJARAN INQUIRY TRAINING \\ TERHADAP HASIL BELAJAR SISWA PADA MATERI POKOK BESARAN DAN SATUAN KELAS X SEMESTER I SMA NEGERI I TANJUNG MORAWA T.P. 2014/2015
}

\author{
Hanna Meilida Flora Sitorus dan Derlina \\ Email: flora_meilida@yahoo.co.id
}

Program Studi Pendidikan Fisika

Fakultas Matematika dan Ilmu Pengetahuan Alam Universitas Negeri Medan

\begin{abstract}
ABSTRAK
Penelitian ini bertujuan untuk mengetahui perbedaan akibat pengaruh model pembelajaran inquiry training terhadap hasil belajar siswa pada materi pokok besaran dan satuan di kelas X semester I SMA Negeri 1 Tanjung Morawa.

Jenis penelitian ini adalah quasi experiment. Populasi dalam penelitian ini adalah seluruh siswa kelas X semester I SMA Negeri 1 Tanjung Morawa yang terdiri dari 6 kelas berjumlah 210 orang. Pengambilan sampel dilakukan dengan cara cluster random sampling dengan mengambil 2 kelas dari 6 kelas secara acak yaitu kelas $\mathrm{X}$ - IPA 3 sebagai kelas eksperimen dan kelas X - IPA 4 sebagai kelas kontrol yang berjumlah 60 orang. Instrumen yang digunakan yaitu tes hasil belajar yang terdiri dari 20 soal pilihan berganda yang terlebih dahulu divalidkan oleh tiga validator. Data awal penelitian diperoleh nilai rata - rata pretes kelas eksperimen adalah 26,67 dan nilai rata - rata kelas kontrol adalah 27. Hal ini menunjukkan bahwa kemampuan awal kedua kelas adalah sama. Kemudian diberikan perlakuan yang berbeda, kelas eksperimen dengan menggunakan model pembelajaran inquiry training dan kelas kontrol menggunakan pembelajaran konvensional. Setelah pembelajaran selesai, diberikan postes sehingga diperoleh nilai rata - rata kelas eksperimen 60 dan kelas kontrol 55. Dari hasil uji t diperoleh $t_{\text {hitung }}=1,739$ sedangkan $t_{\text {tabel }}=1,671$, dimana $t_{\text {hitung }}>t_{\text {tabel }}(1,739>1,671)$.

Hasil penelitian menunjukkan bahwa ada perbedaan akibat pengaruh model pembelajaran inquiry training terhadap hasil belajar siswa pada materi pokok besaran dan satuan di kelas X semester 1 Tanjung Morawa T.P. 2014/2015.
\end{abstract}

Kata Kunci: model pembelajaran inquiry training, konvensional

\section{Pendahuluan}

Salah satu masalah yang dihadapi dunia pendidikan adalah masalah lemahnya proses pembelajaran. Dalam proses pembelajaran, anak kurang didorong untuk mengembangkan kemampuan berpikir. Proses pembelajaran di dalam kelas diarahkan kepada kemampuan anak untuk menghafal informasi. Indonesia meraih peringkat paling bawah terkait dengan mutu pendidikannya berdasarkan data The Learning Curve Pearson 2014. Indonesia menempati posisi ke - 40 dengan indeks rangking dan nilai secara keseluruhan yakni $-1,84$. Sementara 
pada kategori kemampuan kognitif indeks rangking 2014 versus 2012, Indonesia diberi nilai $-1,71$. Sedangkan untuk nilai pencapaian pendidikan yang dimiliki Indonesia diberi skor -2,11. Posisi Indonesia ini menjadikan yang terburuk. Di mana Meksiko, Brasil, Argentina, Kolombia, dan Thailand menjadi lima negara dengan rangking terbawah yang berada di atas Indonesia.

Pelaksanaan pendidikan di sekolah belum sesuai dengan harapan. Bangsa Indonesia memiliki paradigma bahwa perbaikan sektor pendidikan, tidak cukup hanya dengan regulasi soal kurikulum, penyelenggaraan, pengelolaan, pembelajaran dan penilaian, tetapi juga harus dilakukan secara simultan dengan perbaikan sektor SDM guru. Oleh karena itu, akan menjadi menjadi tanggungjawab yang cukup besar bagi guru karena merupakan ujung tombak yang berhubungan langsung dengan siswa sebagai subjek dan objek belajar.

Peningkatan

efektivitas pembelajaran dengan mendorong partisipasi dan aktivitas siswa sebesar-besarnya dalam proses tersebut, serta mendorong guru untuk terus meningkatkan motivasi siswa dalam belajar dengan penggunaan teknologi pembelajaran jawabannya sangat stereotip namun realistis dan memiliki landasan legal yang kuat, bahwa bangsa ini bercita-cita untuk melahirkan generasi bangsa ke depan yang citizens, serta semua yang ideal-ideal, yang bagi bangsa kita. Semua itu masih seperti sebuah mimpi indah yang belum bisa diprediksi seberapa tahun bisa menggapai idealitas tersebut, karena belum memiliki platform yang jelas dalam pembinaan SDM yang memerlukan perbaikan holistis dan komprehensif, tidak cukup perbaikan hanya pada kurikulum sekolah atau perguruan tinggi, manajemen dan strategi pembelajaran, tetapi juga political will serta kesadaran masyarakat tentang perlunya perbaikan sektor pendidikan, dan yang tidak kalah pentingnya adalah kesadaran aparatur pengelola sektor pendidikan dengan mengefesiensikan dan membersihkan biaya birokrasi beserta akses-akses dalam penyelenggaraan sektor pendidikan tersebut. Dalam konteks ini mengajar tidak ditentukan oleh lamanya serta banyaknya materi yang disampaikan, tetapi dari dampak proses pembelajaran itu sendiri.

Proses pembelajaran merupakan sebuah proses yang bertujuan untuk membelajarkan peserta didik. Oleh sebab itu, pembelajaran yang dilakukan oleh seorang guru seharusnya mengarah pada pencapaian tujuan. Pembelajaran yang dilakukan hanya dengan menyampaikan materi pelajaran kurang bermanfaat apabila tidak disertai perubahan tingkah laku. Dalam konteks ini mengajar tidak ditentukan oleh lamanya serta banyaknya materi yang disampaikan, tetapi dari dampak proses pembelajaran itu sendiri. Bisa saja guru hanya beberapa menit di muka kelas, namun dari waktu yang sangat singkat itu membuat siswa sibuk melakukan proses belajar, itu sudah dikatakan mengajar.

Inquiry training bertolak dari kepercayaan bahwa perkembangan seseorang agar mandiri, menuntut metode yang dapat memberi kemudahan bagi para mahasiswa untuk melibatkan diri dalam penelitian ilmiah. Umumnya manusia selalu memiliki rasa ingin tahu, 
karena itu model latihan penelitian ini memperkuat dorongan alami untuk melakukan eksplorasi, memberikan arah khusus sehingga mereka akan dapat melakukan eksplorasi itu dengan semangat besar dan dengan penuh kesungguhan. Dengan model ini membantu siswa untuk melakukan penemuan secara mandiri dengan cara yang berdisiplin. Yang diharapkan ialah siswa dapat mempertanyakan, penyebab terjadinya suatu peristiwa, dan menelitinya dengan cara mengumpulkan dan mengolah data secara logis.

Model pembelajaran sendiri terdiri dari berbagai macam, yang masing-masing model mempunyai keunggulan dan kelemahan. Hingga kini, masih ada beberapa siswa yang beranggapan bahwa fisika sebagai pelajaran yang sulit sehingga siswa kurang termotivasi untuk belajar fisika. Hal ini disebabkan oleh beberapa faktor diantaranya penggunaan model maupun metode pembelajaran yang kurang bervariasi. Pembelajaran inovatif dapat mengadaptasi dari model pembelajaran yang menyenangkan. Pembelajaran berbasis inquiry (penelitian) mengikuti metode sains, yang memberi kesempatan pada siswa untuk belajar bermakna dalam memperoleh pengetahuan. Oleh karena itu di dalam pembelajaran inquiry (penelitian) guru harus selalu merancang kegiatan yang memungkinkan siswa melakukan kegiatan penemuan di dalam proses pembelajaran.

Berdasarkan pengalaman selama PPLT, pembelajaran yang berlangsung masih berpusat pada guru. Peserta didik hanya sebagai penerima informasi yang seringkali terlihat diam dan tidak memberikan respon. Kurangnya minat dan perhatian siswa ketika mengikuti pelajaran fisika. Kondisi ini juga diperkuat melalui hasil observasi yang diperoleh di sekolah SMA Negeri I Tanjung Morawa. Jika ditinjau dari hasil belajarnya diperoleh nilai mata pelajaran fisika siswa masih di bawah nilai KKM (Kriteria Ketuntasan Minimal) 75. Sebanyak $50 \%$ siswa memiliki ratarata skor fisika antara 50-60, 31,58 $\%$ siswa memiliki rata-rata skor antara 40-50, dan 18,42 \% siswa rata-rata skor < 40. Kurangnya minat belajar beberapa siswa ditandai dengan kesiapan siswa sebelum maupun sesudah pembelajaran. Pembelajaran yang dilakukan baik adanya namun masih perlu adanya perbaikan terhadap kebiasaan pembelajaran peserta didik yang lebih memfokuskan pada rumus-rumus tanpa memahami konsep dengan benar. Perubahan mindset peserta sangat diutamakan melalui modep pembelajaran ini.

Berdasarkan hasil penelitian (Lubis, 2010) diperoleh nilai rata-rata pretes 36,00 setelah diberi perlakuan yaitu dengan model pembelajaran inquiry training maka hasil belajar siswa meningkat dengan nilai rata-rata 77,40 . Kelemahan dalam penelitian ini adalah peneliti kurang mampu memanfaatkan waktu dalam bekerja sama sehingga saat pengumpulan tugas, siswa terburu-buru mengerjakan tugas. Dan siswa mengalami kesulitan dalam pelaksanaan kerja kelompok. Penelitian lain oleh (Indahwati,dkk, 2012) dalam jurnal inkuiri dengan penerapan model pembelajaran inquiry training melalui teknik peta konsep dan teknik puzzle diperoleh hasil bahwa tidak ada pengaruh model pembelajaran inquiry training 
melalui teknik peta konsep maupun teknik puzzle. Adapun yang menjadi kelemahan model pembelajaran inquiry training secara umum terlihat saat proses pembelajaran, tenaga pendidik sulit mengontrol kegiatan dan keberhasilan siswa, kriteria keberhasilan belajar yang ditentukan oleh penguasaan terhadap materi pelajaran maka akan sulit diimplementasikan oleh guru, terbentur dengan kebiasaan siswa dalam belajar, dan sulit menyesuaikan dengan waktu yang telah ditentukan.

Menurut hasil penelitian yang dilakukan oleh peneliti sebelumnya maka peneliti tertarik untuk melakukan penelitian dengan materi pokok, dan tempat penelitian yang berbeda serta peneliti akan mencoba menutupi dan meminimalisir kelemahan dari penelitian sebelumnya dengan cara memberitahukan terlebih dahulu kepada siswa alokasi waktu saat melakukan praktikum dan menginformasikan kepada siswa langkah-langkah diskusi yang akan dikerjakan serta memaksimalkan penggunaan media agar lebih efisien. Mengubah mindset siswa terhadap pembelajaran konvensional dan berusaha menyajikan pembelajaran yang inovatif melalui teknik, strategi dan metode pembelajaran yang memicu semangat belajar serta mengubah kebiasaan belajar siswa.

\section{Metode Penelitian}

Penelitian ini menggunakan desain pre-test and post-test group. Diberikan perlakuan yang berbeda kepada kedua kelas sampel. Kelas eksperimen menggunakan model pembelajaran inquiry training dan kelas kontrol menggunakan pembelajaran konvensional. Untuk mengetahui hasil belajar siswa yang diperoleh malalui perlakuan tersebut, maka siswa diberi tes. Desain penelitian ini secara singkat ditunjukkan pada Tabel 1.

Tabel 1 Desain pre-test and pos-test group

\begin{tabular}{|l|c|c|c|}
\hline \multicolumn{1}{|c|}{ Sampel } & Pretes & Perlakuan & Postes \\
\hline Eksperimen & $\mathrm{O}$ & $\mathrm{X}_{\mathrm{a}}$ & $\mathrm{O}$ \\
\hline Kontrol & $\mathrm{O}$ & $\mathrm{X}_{\mathrm{b}}$ & $\mathrm{O}$ \\
\hline
\end{tabular}

Keterangan:

$\mathrm{O}$ :Instrumen hasil belajar kognitif

$\mathrm{X}_{\mathrm{a}}$ :Pembelajaran menggunakan model pembelajaran inquiry training

$\mathrm{X}_{\mathrm{b}}$ :Pembelajaran konvensional.

Populasi dalam penelitian ini adalah seluruh siswa/i kelas X SMA Negeri 1 Tanjung Morawa T.P 2014/2015 yang terdiri dari enam kelas.

Pengambilan sampel dilakukan dengan cara cluster random sampling dengan mengambil dua kelas, secara acak yaitu kelas X IPA-3 sebagai kelas eksperimen dan kelas X IPA-4 sebagai kelas kontrol.

Variabel bebas dalam penelitian ini adalah model pembelajaran inquiry training dan pembelajaran konvensional. Variabel terikat dalam penelitian ini adalah hasil belajar fisika siswa pada materi pokok besaran dan satuan.

Pengumpulan data untuk ranah kognitif dalam penelitian ini menggunakan instrumen penelitian dalam bentuk tes hasil belajar. Dalam penelitian ini peneliti menggunakan tes dalam bentuk pilihan ganda sebanyak dua puluh soal dengan lima options. Dimana soal yang benar diberi skor 1 dan jawaban yang salah diberi skor 0. Sebelum dipergunakan, instrumen penelitian ini terlebih dahulu harus melalui uji validitas isi.

Pengumpulan data penelitian untuk aktivitas belajar diperoleh 
dengan menggunakan instrumen penelitian dalam bentuk lembar observasi yang terdiri dari empat aspek penilaian dengan skor tertinggi 4 dan diisi oleh observer.

Setelah data terkumpul, untuk data dalam ranah kognitif dilakukan uji normalitas dengan menggunakan uji Liliefors, uji homogenitas dengan menggunakan uji varians dan uji hipotesis dengan menggunakan uji t. Sedangkan untuk aktivitas dilakukan observasi aktivitas.

\section{Hasil dan Pembahasan}

\section{Hasil Penelitian}

Hasil penelitian ini menunjukkan bahwa ada perbedaan akibat pengaruh model pembelajaran inquiry training terhadap hasil belajar siswa, hal ini ditunjukkan dari nilai rata-rata pretes pada kelas kontrol sebesar 27 dan postes 55, sedangkan pada kelas eksperimen nilai rata-rata pretes sebesar 26,67dan postes 60. Kedua kelas sampel memiliki perbedaan nilai rata-rata, untuk kelas kontrol mengalami peningkatan hasil belajar sebesar 28 sedangkan pada kelas eksperimen sebesar 33,33.

Berdasarkan observasi yang dilakukan oleh observer, diperoleh hasil bahwa aktivitas belajar siswa mengalami peningkatan. Siswa bersemangat mengikuti setiap kegiatan yang dilakukan selama proses pembelajaran. Jumlah siswa yang aktif bertanya juga meningkat setiap pertemuannya. Siswa juga terlihat cukup tertarik mengerjakan setiap percobaan dalam kelompok. Setiap anggota kelompok berusaha mengerjakan percobaan sebaik mungkin agar dapat memperoleh hasil yang terbaik. Hal ini lah yang membuat model pembelajaran inquiry training mampu meningkatkan aktivitas belajar siswa. Pada pertemuan I diperoleh nilai rata-rata $63 \%$, pertemuan II

diperoleh nilai rata-rata $66,67 \%$ dan pertemuan III diperoleh nilai ratarata $66,5 \%$.

Uji normalitas data dilakukan dengan menggunakan uji Liliefors pada taraf nyata $\alpha=0,05$ dan $\mathrm{n}_{1}=30$ dan $\mathrm{n}_{2}=30$, dan diketahui bahwa data pretes yaitu kelas eksperimen Lhitung $<$ Ltabel $(0,1240<0,1610)$ dan kelas kontrol $0,1461<0,1610$ maka berdistribusi normal.

Uji homogenitas data dilakukan dengan menggunakan uji $\mathrm{F}$ pada taraf nyata $\alpha=0,1$ dengan $\mathrm{dk}$ pembilang $=29$ dan $\mathrm{dk}$ penyebut $=29$, dan diketahui bahwa data pretes dengan harga $F_{\text {hitung }}<\mathrm{F}_{\text {tabel }}$ $(1,0108<1,8594)$ berasal dari populasi yang homogen.

Uji hipotesis data dilakukan dengan menggunakan uji t satu pihak pada taraf nyata $\alpha=0,05 \mathrm{dan} \mathrm{dk}=58$ yang diperoleh dari interpolasi linear menunjukkan bahwa $t_{\text {hitung }}>\mathrm{t}_{\text {tabel }}$ $(1,738>1,671)$ sehingga $H_{a}$ diterima atau dengan kata lain ada perbedaan akibat pengaruh Model Pembelajaran Inquiry Training terhadap hasil belajar siswa pada materi pokok besaran dan satuan kelas X Semester I SMA Negeri Tanjung Morawa T.P 2014/2015.

\section{Pembahasan}

Model pembelajaran inquiry training lebih baik dari pada pembelajaran konvensional, karena memberikan peluang kepada siswa secara aktif terlibat dalam kegiatan pembelajarannya, hal ini terlihat melalui fase demi fase dalam model ini khususnya fase kedua, dimana siswa mengumpulkan data-verifikasi untuk menyatakan kebenaran suatu permasalahan serta memecahkan masalah terkait materi yang dibahas 
melalui eksperimentasi. Melalui eksperimen siswa dituntut untuk dapat memberdayakan kemampuan berpikir sesuai pengetahuan yang dimiliki, dalam hal mengemukakan hipotesis percobaan dan menganalisis hasil percobaan, serta menarik kesimpulan, sehingga apa yang diperoleh oleh siswa tidak hanya mengingat fakta-fakta melainkan menemukan langsung fakta. Keterlibatan siswa secara aktif dalam kegiatan pembelajaran inquiry training juga terlihat melalui fase keempat, dimana siswa secara berkelompok ditugaskan untuk mengolah serta merumuskan penjelasan terkait hasil eksperimen dalam bentuk laporan diskusi, dengan diskusi siswa akan berusaha menemukan dan mempelajari konsep-konsep materi pelajaran serta berusaha untuk memunculkan ide-ide yang dimiliki dalam hal pemecahan masalah yang dibahas, dengan kegiatan ini maka siswa tidak hanya sekedar mengingat materi pelajaran yang dibahas, akan tetapi siswa mampu menguasai dan memahaminya secara penuh. Dalam fase ini juga siswa secara berkelompok ditugaskan untuk mempresentasikan kepada teman dan guru hasil laporan diskusi yang dikerjakan, sehingga dengan kegiatan ini siswa akan memperoleh kemampuan berkomunikasi dalam presentasi, menanggapi pendapat orang lain, bertanggung jawab dan berpikir logis yang merupakan cerminan dari sikap, hal ini terlihat dari hasil observasi sikap siswa selama kegiatan pembelajaran mengalami peningkatan tiap pertemuan. Melalui fase tersebut juga, keterampilan siswa akan muncul, misalanya keterampilan dalam melakukan percobaan, menggunakan alat praktikum, dan mengumpulkan data percobaan, serta membuat laporan hasil diskusi, hal ini dapat dilihat dari hasil observasi keterampilan siswa selama pembelajaran berlangsung, nilai keterampilan siswa meningkat tiap pertemuan.

Berdasarkan hasil penelitian, diperoleh hasil belajar kelas eksperimen mengalami peningkatan yaitu 26,67 menjadi 60. Namun nilai tersebut masih di bawah nilai KKM yaitu 75. Dalam pelaksanaan penelitian ini, peneliti berusaha meminimalisir kesulitan yang pernah terjadi saat menerapkan model pembelajaran inquiry training. Efisiensi waktu sangat diperhatikan ketika siswa bereksperimen. Oleh karena itu, setiap fase dalam model ini dapat dilaksanakan dengan baik dan mencapai tujuannya masing masing. Penelitian dari jurnal inkuiri dengan penerapan model pembelajaran inquiry training melalui teknik peta konsep dan teknik puzzle mengalami kesulitan untuk menentukan kriteria keberhasilan belajar yang ditentukan oleh penguasaan terhadap materi pelajaran serta terbentur dengan kebiasaan siswa dalam belajar. Dalam hal ini, peneliti memberikan demonstrasi dan eksperimen untuk mengubah mindset siswa tentang kebiasaan belajar selama ini.

Model pembelajaran inquiry training dapat juga meningkatkan aktivitas belajar siswa, hal ini ditunjukkan dari hasil observasi aktivitas belajar siswa, mulai pertemuan I. Pada pertemuan ini aktivitas belajar siswa tergolong masih kurang aktif. Tetapi seiring dengan berlangsungnya pembelajaran yang melibatkan siswa dalam kegiatan pembelajarannya, dimana siswa melakukan 
eksperimen, membuat laporan hasil diskusi, mengajukan pertanyaan dan memberikan pendapat untuk pemecahan masalah, sehingga siswa termotivasi untuk belajar aktif hingga pertemuan III, aktivitas belajar siswa menjadi meningkat dengan kategori cukup aktif. Keterlibatan siswa secara aktif dalam pembelajaran akan dapat meningkatkan hasil belajar siswa dan sikap siswa lebih baik tehadap suatu pelajaran. Hasil belajar siswa di kelas eksperimen lebih baik adalah akibat pengaruh penggunaan model pembelajaran inquiry training. Pencapaian hasil belajar kurang maksimal. Kendala-kendala tersebut adalah seperti; 1) pada saat menyajikan hasil diskusi, sebagian siswa kurang antusias untuk presentasi melainkan memilih diam dan menunggu pendapat temannya, hal ini dikarenakan siswa masih pertama kali menerima model pembelajaran inquiry training sehingga kurang memahami kegiatan pembelajaran yang berlangsung dan kemampuan siswa pada kelas eksperimen masih tergolong rendah, yaitu memperoleh rata-rata pretes 26,67 sehingga kurang mendukung terlaksananya pembelajaran ini. dibantu oleh dua orang observer. Jika ingin melakukan penelitian menggunakan model pembelajaran inquiry training, seorang peneliti harus menambah jumlah observer dari jurusan yang sama dengan peneliti untuk membantu peneliti saat siswa melakukan eksperimen serta mengkoordinir kondisi kelas sehingga kondusif.

\section{Penutup}

\section{Kesimpulan}

Berdasarkan hasil analisis dan uji statistik serta pembahasan, adapun kesimpulan yang diperoleh dari penelitian yang dilakukan di kelas $\mathrm{X}$ SMA Negeri 1 Tanjung Morawa T.P 2014/2015 pada materi pokok besaran dan satuan ini adalah ada perbedaan akibat pengaruh model pembelajaran inquiry training terhadap hasil belajar siswa. Selama proses pembelajaran, aktivitas belajar siswa meningkat dari pertemuan I dengan persentasi nilai rata - rata 63\% kategori kurang aktif hingga pertemuan III $66,5 \%$ menjadi cukup aktif.

\section{Saran}

Berdasarkan hasil penelitian dan kesimpulan di atas, maka sebagai tindak lanjut dari penelitian ini disarankan beberapa hal sebagai berikut : Sebelum model ini diterapkan,sebaiknya memahami terlebih dahulu tiap fase atau sintaks dari model pembelajaran inquiry training sehingga model pembelajaran ini dapat diterapkan dengan benar. Memperhatikan efisiensi waktu khususnya pada fase ketiga saat melakukan investigasi melalui eksperimen, perlunya penjelasan kepada siswa prosedur praktikum yang akan dikerjakan, seorangpeneliti membutuhkan observer minimal tiga orang untuk membantu peneliti memantau siswa saat melakukan eksperimen.

\section{Daftar Pustaka}

Anderson dan David, (2010), Pembelajaran, Pengajaran dan Asesmen, Pustaka Pelajar, Yokyakarta

Anonim,(2010),http://kbbi.web.id/ko nvensional

Arikunto, Suharsimi, (2010), Prosedur Penelitian Suatu Pendekatan Praktik, Penerbit Rineka Cipta, Jakarta 
Astra, I Made, Hilman Setiawan, (2007), Fisika Untuk SMA dan MA Kelas XI, Penerbit Piranti Darma Kalokatama, Jakarta

Dimyati dan Mudjiono, (2013), Belajar dan Pembelajaran, Penerbit Rineka Cipta, Jakarta

Harahap, Rachmad, Faisal, (2014), Alasan Mutu Pendidikan Indonesia Masih Jelek, http ://m.okezone.com/read/2014 /05/13 (diakses 20 juni 2014)

Indahwati, Toenas Setyo Joeli, Widha Sunarno, Sajidan, (2012), Penerapan Model Inquiry Training Melalui Teknik Peta Konsep dan Teknik Puzzle ditinjau dari Tingkat Keberagaman Aktivitas Belajar dan Kemampuan Memori, Jurnal Inkuiri, Vol 1 : 258265

Istarani,(2012), $58 \quad$ Model Pembelajaran Inovatif, Media Persada, Medan

Jihad, Asep, Abdul Haris, (2013), Evaluasi Pembelajaran, Multi Pressindo, Yokyakarta

Joyce, Bruce, dkk, (2009), Models of Teaching Model-model Pengajaran, Penerbit Pustaka Pelajar, Jakarta

Kanginan, Marthen, (2006), Fisika Untuk SMA Kelas $X$, Penerbit Erlangga, Jakarta

Lubis, Nurhaida, (2010), Pengaruh Model Pembelajaran Latihan Inkuiri (Inquiry Training Learning Model) Terhadap Hasil Belajar Siswa Pada Materi Pokok Zat dan Wujudnya Kelas VIII MTs N 3 Medan T.P
2009/2010, Skripsi FMIPA Unimed, Medan

Rosyada, Dede, (2007), Paradigma Pendidikan Demokratis, penerbit Kencana, Jakarta

Slameto, (2010), Belajar dan faktorfaktor yang mempengaruhinya, Penerbit Rineka Cipta, Jakarta

Sudirman, (2010), Fisika Kelompok Teknologi dan Kesehatan, Penerbit Erlangga, Jakarta

Sudjana, (2005), Metoda Statistika, PT.Tarsito, Bandung.

Sugiyono, (2010), Metode Penelitian Kuantitatif, Kualitatif, dan $R \& D, \quad$ Penerbit ALFABETA,cv, Bandung

Trianto, (2013), Mendesain Model Pembelajaran Inovatif, Progresif, Konsep Landasan dan Implementasinya Pada Kurikulum Tingkat Satuan Pendidikan (KTSP), Kencana Predana Media Group, Jakarta

Widodoaji, (2012), Manfaat dimensi dalam fisika, http://mgmpfisikabanyumas. wordpress.com/2012/03/15/ apa-manfaat-dimensidalam-fisika/ (diakses 24 juni 2014)

Zanuar, (2010), Besaran Pokok, Tambahan dan Turunan Dalam Sistem Internasional, http : ://forum.upi.edu (diakses 20 juni 2014) 